\title{
CLIMATE-INDUCED CYCLICAL PROPERTIES OF REGIONAL WINE PRODUCTION USING A TIME-FREQUENCY APPROACH IN DOURO AND MINHO WINE REGIONS
}

\author{
PROPRIEDADES CÍCLICAS DA PRODUÇÃO REGIONAL DE VINHO INDUZIDAS PELO CLIMA \\ USANDO UMA ABORDAGEM DE FREQUÊNCIA TEMPORAL NAS REGIÕES VINÍCOLAS DO \\ DOURO E MINHO
}

\begin{abstract}
Mario Cunha ${ }^{1,2^{*}}$, Christian Richter ${ }^{3}$
${ }^{1}$ Faculdade de Ciências, Universidade do Porto, Rua do Campo Alegre, 4169-007, Porto, Portugal. ${ }^{2}$ INESC TEC, Campus da FEUP, Rua Dr. Roberto Frias, 4200 - 465 Porto, Portugal.

${ }^{3}$ German University in Cairo, Faculty of Management Technology, 11835 New Cairo City, Egypt.

* Corresponding author: +351 220402 489, e-mail: mccunha@fc.up.pt, mario.cunha@inesctec.pt
\end{abstract}

(Received 03.02.2020. Accepted 19.05.2020)

\section{SUMMARY}

The impact of climate on wine production (WP) temporal cycles in Douro (DR) and Vinhos Verdes (VVR) wine regions for a period of about 80 years, characterized by strong technological trend and climate variability, was modelled. The cyclical properties of WP, and which cycles are determined by spring temperature (ST) and soil water during summer (SW), were identified. It was achieved by applying a time-frequency approach, which is based on Kalman filter in the time domain. The time-varying autoregressive model can explain more than $67 \%$ (DR) and $95 \%$ (VVR) of the WP' variability and the integration of the ST and mainly SW increase the models' reliability. The results were then transferred into the frequency domain, and can show that WP in both regions is characterized by two cycles close to 5-6 and 2.5 years around the long run trend. The ST and SW showed great capacity to explain the cyclicality of WP in the studied regions being the coherence temporarily much more stable in VVR than in the DR, where a shift of the relative importance away from ST to SW can be recognized. This could be an indicator of lower impact of the foreseen hot and dry climate scenarios on WP in the regions with a maritime climate, such as the VVR, compared with hot and dry wine regions. Despite the marked differences in the two studied regions on ecological, viticulture practices and technological trend, the modelling approach based on time-frequency proved to be an efficient tool to infer the impact of climate on the dynamics of cyclical properties of regional WP, foreseeing its generalized use in other regions. This modelling approach can be an important tool for planning in the wine industry as well as for mitigation strategies facing the scenarios that combine technological progress and climate change.

\section{RESUMO}

Este trabalho apresenta uma metodologia inovadora para avaliar o impacto do clima nos ciclos temporais da produção anual de vinho (WP) nas regiões do Douro (DR) e Vinhos Verdes (VVR) para um período de cerca de 80 anos, caraterizado por uma forte evolução tecnológica e variabilidade climática. Numa primeira fase foram identificadas as propriedades cíclicas da WP nestas regiões, seguida da análise de quais destes ciclos são determinados pela temperatura no período da primavera (ST) e água no solo durante o período de verão (SW), estimado através da aplicação Vineyard Soil Irrigation Model (VSIM). Os ciclos da WP em ambas as regiões foram identificados através de um modelo autorregressivo variável no tempo com estimação dos parâmetros com o Kalman filter, seguido da transformação do domínio do tempo para a análise espectral (frequência) das WP através da função Fast Fourier Transform, sendo a coerência utilizada para a análise espectral cruzada entre WP e o clima (ST ou SW). O modelo autorregressivo com variabilidade temporal permite explicar 67\% (DR) e 95\% (VVR) da variabilidade temporal da WP e a integração da ST e, sobretudo, da WP, aumenta muito a confiabilidade do modelo. Posteriormente, os resultados foram transferidos no domínio do tempo para a frequência, o que permitiu demonstrar que a WP, em ambas as regiões, é caracterizada por um ciclo de 5 a 6 anos e outro de 2,5 anos em torno da tendência a longo prazo. A ST e SW apresentaram grande capacidade para explicar os ciclos da WP nas regiões estudadas, sendo a coerência entre ciclos de produção e do clima mais estáveis na VVR que na DR. Na DR verifica-se uma transferência da importância relativa da ST para a SW ao longo dos anos. Os resultados indiciam um menor impacte nos ciclos da WP, dos alegados cenários climáticos nas regiões com clima marítimo (VVR), quando comparadas com as regiões mais quentes e secas como a DR. Apesar das regiões estudadas apresentarem grandes diferenças, tais como condições ecológicas, castas, práticas vitivinícolas e evolução tecnológica, a abordagem

16

This is an Open Access article distributed under the terms of the Creative Commons Attribution License (http://creativecommons.org/licenses/by/4.0), which permits unrestricted use, distribution, and reproduction in any medium, provided the original work is properly cited. 
estatística inovadora apresentada neste trabalho mostrou ser uma ferramenta robusta para inferir o impacte do clima na dinâmica das propriedades cíclicas da WP, prevendo-se a sua potencial generalização a outras regiões vitivinícolas. A abordagem de modelação apresentada pode ser um instrumento importante para o planeamento da indústria vitivinícola, bem como para a definição de estratégias de mitigação de cenários que combinam progresso tecnológico e alteração climáticas.

Key words: Climate variability, technological trend, time-varying spectra, Kalman filter, Douro Region, Vinhos Verdes Region. Palavras-chave: Variabilidade climática, tendência tecnológica, espectro variável no tempo, Kalman filter, Região do Douro, Região dos Vinhos Verdes.

\section{INTRODUCTION}

In Portugal grapevines are one of the most important perennial crops, growing in over 30 different denominations of origin, which support a reputed wine industry strongly linked to specific wine regions (Moriondo et al., 2013; IVV, 2018). The operational efficiency of this wine industry is strongly influenced by regional annual wine production (WP) as well as its inter-annual variability (Cardell et al., 2019). Unpredictable temporal variability of WP is a major threat for farmer and its associations, wine sellers, insurances, researchers, natural resources managers and policy makers among others (Quiroga and Iglesias 2009; Cunha et al., 2010). Therefore, there is a strong demand of adequate study of time series of regional WP in order to improve the efficiency of vineyard and winery operations as well as to support commercial strategies and sectorial planning measures (Cunha et al., 2016). The National Governments and European Commission's policy makers can use information from WP time series to implement regulator mechanisms provided under the Common Organization of Wine Market for moderating the impact of the inter-annual variability of WP in order to protect the denominations of origin (EU-CMO, 2019). Also, long-term analysis of WP would have a key importance, at the light of the recent global and regional climate change scenarios (Jones, 2012; Santos et al., 2013), in order to plan future mitigation actions for viticulture and wine industry (Hannah et al., 2013; Mosedale et al., 2016).

In Portugal, as in many other worldwide wine regions, despite unremitting improvements in vineyard technology, wine-yield remains highly dependent on the short and long-term climate, which causes important variations in WP with several adverse effects for all the contributors involved in vineyard and wine industry as a whole (Bisson et al., 2002; Bock et al., 2013; Fraga et al., 2016; Fraga and Santos, 2017). This effect might be exacerbated, at least in the drier regions of the Mediterranean basin, where the foreseen climate scenarios pointed for substantial drying with precipitation reductions of more than $25 \%$ and warming by $3-5{ }^{\circ} \mathrm{C}$ by 2080 . At the same time, inter-annual variability is projected to increase, especially in summer (IPCC, 2007; Giorgi and Lionello, 2008; Jones, 2012).

Other than the weather impact, agronomic decisions are also known to influence temporal variability of WP. For example, the recent adoption of common high-yielding grape varieties, uniform agronomic practices (e.g. irrigation) based on few grape varieties/clones with common timing of phenological dates (e.g. flowering) have caused grape-yields to become more strongly influenced by weather patterns (Martins et al., 1998), especially under the foreseen climate scenarios.

Because of the complexity and data requirements of grapevine-process based yield models (Bindi et al., 1996; Cola et al., 2014), many of the impact assessments of the past, present and future climate conditions on wine yield have been carried out based on statistical models supported by long-term time series of WP and climate (e.g. Gouveia et al., 2011; Santos et al., 2011; Bock et al., 2013; Bonnefoy et al., 2013; Cunha and Richter, 2016; Teslić et al., 2019). However, there is still very little evidence how sensitive is the temporal variability of WP to the scenarios that combine technological progress and actual or future climate variability. This is largely due to the perennial nature of grapevine wherein cluster structures present in one year begin their development in the spring/summer of the previous year (Vasconcelos et al., 2009). Therefore, current-year production being physiologically dependent on conditions (ecological and agronomic) of the previous year and short-term carryover effects of carbon and water deficits could be expected (Guilpart et al., 2014; Maxwell et al., 2016). These carryover effects (short-term) coupled with long-term (technological and climate) effects on WP make difficult the development of WP dynamics models and could explain the scarcity of well stabilized and generalized models to support wine industry.

Indeed, regional time series of WP are emanated from complex biophysical system of which we know little (Clingeleffer et al., 2001). The WP time series are not stationary and include transitory components, consisting of a variety of frequency regimes that may be localized in space or have short-lived transient 
components and features at different scales (Cunha and Richter, 2016). Stationarity means not only that a series has a constant mean and constant and finite variance, but also that the autocovariances are not functions of time (Ye et al., 2015). Predictable behaviour of such WP system like trends and cyclicality proprieties, is therefore of great interest but a challenging research line in order to develop dynamic models.

During the last decades several studies based on autoregressive model (Cunha and Richter, 2012), climate (Esteves and Orgaz, 2001; Fraga et al., 2014) or measures of radial grape growth rings (Maxwell et $a l ., 2016)$, point towards identifiable induced-climate cyclicality of WP. Results from this previous works show that the time series frequency analysis fits well the impact of climate on WP or vegetation growth in Douro Wine Region (DR). However, an open question is whether this approach to predict the impact of climate dynamics on WP can be transferred to another wine region? For example, a wine region with strong technological change.

This paper provides a long-term analysis of inducedclimate cyclicality of WP in Douro (1933-2013) and Vinhos Verdes (1937-2016) wine regions. Specifically, about eighty years of WP and climate data from two wine regions in Portugal very different in terms of ecological conditions, vineyards techniques and technological trend, are examined to see how there WP patterns are affected by climate. Firstly, the frequency location of the variance in the WP was performed in order to find the dominating cycles. The second step, identifies the importance of climate variability for the cyclical properties of WP, and analyse the predictability of these events. A timefrequency approach is applied, which not only gives the cyclical properties of WP, but also how they changed over time, may be due to climate variability. The Kalman Filter is used to estimate the parameters in the time domain which are then transferred into the frequency domain.

\section{MATERIAL AND METHODS}

\section{Douro and Vinhos Verdes wine regions}

This paper analysis the two main wine regions of Portugal: 'Vinhos Verdes' appellation of Origin (VVR) and the Douro Demarcated Region (DR) (Figure 1). These regions represent at about 32\% of Portugal' vineyard area and $37 \%$ of the wine production (IVV, 2018).

The mountainous areas in the East and South part of VVR, forming the natural border between the Atlantic
Entre-Douro-e-Minho and the Mediterranean inland region belong to the Douro Valey. Therefore, although these wine regions are close, they have rather different climatic, soils and topography conditions as well as distinct viticulture.

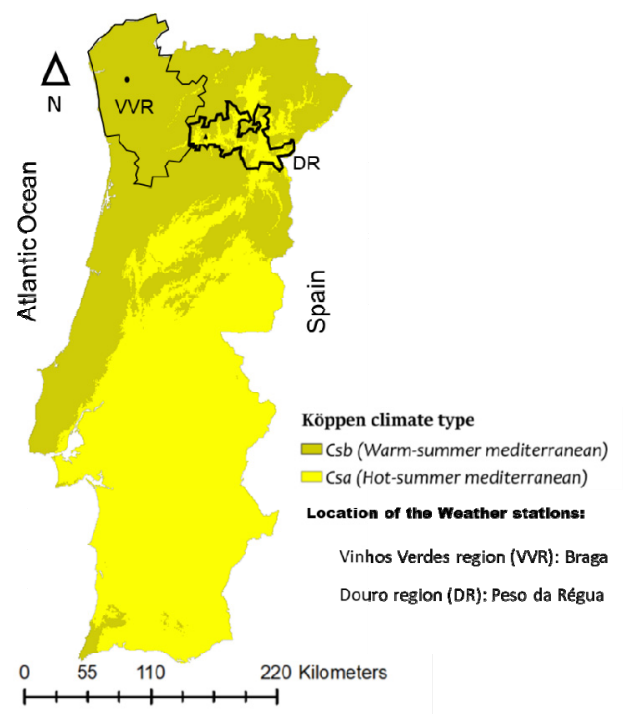

Figure 1. Köppen climate types of Portugal and boundaries of the studied wine regions: Vinhos Verdes (VVR) and Douro (DR) location the weather station within each wine region.

Classificação climática de Köppen para Portugal e localização das regiões vitivinícolas estudadas: Vinhos Verdes (VVR) e Douro (DR) com localização das estações climáticas em ambas as regiões.

The VVR is located in the northwest part of Portugal in an area traditionally known as Entre-Douro-eMinho, the most Atlantic wine region of Portugal. Grapevines grown in VVR have unique characteristics, namely, the form of guiding systems with wide vegetative expansion and growth high above the ground.

The DR is located in northeast part of the country, where vineyards are mainly built over terraces and slopes with soils mostly derived from shale. Also, mostly in the eastern part of this region, the vineyards are located in some of the most arid, non-irrigated, regions of Europe. This region, famous for its Port wine, is responsible for about one fourth $(23 \%)$ of all wine produced in Portugal (IVDP, 2018), and its vineyard landscape is also considered World Heritage by the UNESCO since 2001.

In the $\mathrm{DR}$, red grape varieties predominate, while in VVR the most frequent varieties are the white ones. 
The average temperature for the year in VVR ranges between 12.5 and $15.8^{\circ} \mathrm{C}$, and in DR is 11.8 and 16.5 ${ }^{\circ} \mathrm{C}$. The warmest month, on average, is August in both regions with an average temperature of $20^{\circ} \mathrm{C}$ (VVR) and $24.4{ }^{\circ} \mathrm{C}$ (DR), and the coolest month on average is January, with an average temperature of $8.8^{\circ} \mathrm{C}$ (VVR) and $8.0{ }^{\circ} \mathrm{C}$. The average amount of annual precipitation varies from 1200 to $2000 \mathrm{~mm}$ in VVR and 400 to $800 \mathrm{~mm}$ in DR, most of which occur in autumn and winter.

According to Köppen's classification, VVR belongs to the climate type Csb, while the climate in DR is Csa type (Figure 1). The Csb is characterized by mild climate with dry and hot summers with average temperatures below $22{ }^{\circ} \mathrm{C}$, and has four months of the year when temperatures do not fall below $10^{\circ} \mathrm{C}$. The Csa is mild climate with dry and hot summers, with average temperatures in the hottest month exceeding $22{ }^{\circ} \mathrm{C}$.

During the period April - October, the mean temperature is about $17.1{ }^{\circ} \mathrm{C}$ in VVR and $19.5{ }^{\circ} \mathrm{C}$ in $\mathrm{DR}$, and according to the climate maturity grouping (Jones, 2007), the growing season can be defined as 'Intermediate' and 'Hot', respectively.

In the VVR, with a wetter post-flowering period, diseases incidence generated production losses are frequent. In the DR, being hotter and drier after flowering, the problems associated with grape diseases are less frequent (Cunha et al., 2003).

The soil in which the Douro Valley vines are planted is 'made up' of schist being classified as Lithosols (IVDP, 2018), which are very different of the Cambisols that predominate in the VVR (CVRVV, 2018).

\section{Regional wine production and climate data}

The annual wine production data used in this work was provided by: 'Instituto dos Vinhos do Douro e Porto' (IVDP, 2018) for DR (1933-2013) and 'Comissão de Viticultura da Região dos Vinhos Verdes' (CVRVV, 2018) for VVR (1937-2016).

In this paper, the meteorological observations collected from weather stations located within each studied region are used (Figure 1): i) in DR, 'Peso da Régua' $\left(41^{\circ} 10^{\prime} \mathrm{N}, 7^{\circ} 47^{\prime} \mathrm{W}\right)$, for the years $1933-2013$ :

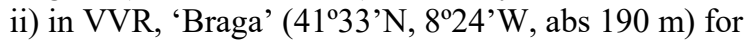
the period 1941-2016.

The period analysed in DR region is not contemporary of the one analysed for VVR: WP (VVR, 1937-2016) and climate (1941-2016). However, unmatched difference of 6 years for WP overlap period (1937-2013) and 10 years for climate overlap period (1941-2013) are reasonably small not to jeopardize the stability of the results.

The weather data used in this work consist of daily observations for mean, maximum and minimum temperature and precipitation. The daily weather was aggregated to extract some soil-climate metrics (e.g. available soil water, $\mathrm{mm}$ ) and also converted to temporal seasonal periods: Spring temperature (ST) and Soil Water in the summer (SW).

These periods were selected because they are related to WP variability as mentioned in a previous paper by Cunha and Richter (2016). The ST includes a period of high intensity of growth and the reproductive phase between flowering and fruit-set which are physiological dependent of temperature, while the SW period includes the vegetative phase between veraison and harvest, characterized by strong potential hydric stress.

The daily weather data for VVR (1941 to 2016) and DR (1950 to 2013) were both obtained from "Instituto Português do Mar e da Atmosfera (IPMA)", while for the period 1933 to 1950 in DR, it was from the "Serviço Meteorológico Nacional" (data in paper).

Daily weather data covering all the period analysed were subject to quality control to examine outliers, adjust missing data values, and check the temporal homogeneity of the data, using the procedures developed by Peterson et al. (1998) and applied by Jones (2012) in DR. The R_Studio application RHtestsV4 was used for the assessment of the quality of the meteorological data: http://etccdi.pacificclimate.org/software.shtml.

\section{Soil water balance}

In this paper, metrics of annual vineyard soil water status for the period 1933 to 2013 in DR and 1941 to 2016 in VVR were simulated by using the Vineyard Soil Irrigation Model (VSIM). The VSIM has been used for simulation of daily and seasonal soil water balance for vineyard based on weather (rainfall, temperature), soils (texture, rooting depth), and leaf area index (LAI). The background and computation of VSIM is fully described by Pierce et al. (2015).

The VSIM model has been validated for vineyards in different wine regions with good results (e.g. Johnson et al., 2006), and it was also validated in Portugal (Cunha and Richter, 2016).

The daily reference evapotranspiration used in the soil water balance, was estimated based on Hargreaves-Samani method (Hargreaves and Samani, 1985), which requires only temperature data and the Ref_ET software (Allen, 2015) was used for the computational procedures. 


\section{Time-frequency analysis of the wine production}

\section{First step: Estimation in the Time Domain}

In the first step, we estimate the cyclic behaviour of each individual variable, i.e. wine production (WP), spring temperature (ST) and soil water (SW) using an Autoregressive Model of order "p" (AR(p)), where $p$ is determined using information criteria such as the Akaike Information Criterion (AIC). In order to allow for possible changes in the parameters, we use a timevarying $A R(p)$ model by applying the Kalman filter. The Kalman filter is sometimes described as an "optimal recursive data processing algorithm" (Maybeck, 1979). The Kalman filter is optimal in the sense that it combines all available measurement data and prior knowledge about the system to produce an estimate of the desired variable so that the error is minimised statistically. The Kalman filter estimates a process by using a form of feedback control: the filter estimates the process state at some time and then obtains feedback in the form of (noisy) measurements. As such, the equations for the Kalman filter fall into two groups: the state equations and the measurement update equations. The state equations are responsible for projecting forward (in time) the current state (and error covariance). The measurement equations use the input of the state equation for generating a new measurement, that is, to obtain an improved a posteriori estimate. The measurement equation is equation 1 , where $y_{t}$ is the variable of interest, for example WP. As above-mentioned, it is assumed in the first step that the dependent variable follows an autoregressive process with a maximum number of 9 lags:

$\mathrm{y}_{\mathrm{t}}=\alpha_{0, \mathrm{t}}+\sum_{\mathrm{i}=1}^{9} \alpha_{\mathrm{i}, \mathrm{t}} \mathrm{y}_{\mathrm{t}-\mathrm{i}}+\varepsilon_{\mathrm{t}}$

where

$\sigma_{t} \approx t_{i}, d,\left(0, \sigma_{\varepsilon}^{2}\right) \forall t$

It was never found more than lag 9 to be significant, and it only serves as a starting assumption. As lags may be eliminated in the estimation process, the order of the AR model may well be below 9 .

Equation 2 is the state equation and provides the estimates for the parameters $\alpha_{\mathrm{s}}$ of the autoregressive process (1). It is assumed a random walk process of the form:

$\alpha_{i, t}=\alpha_{i, t-1}+\eta_{i, t}$, for $i=0 \ldots 9$

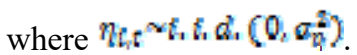

Furthermore, $\boldsymbol{s}_{i}$ and $\eta_{i_{i} t}$ are white-noise processes, independent of each other. $z_{t}$ and $\eta_{i_{i} t}$ follow each one an independent multivariate normal distribution.

A general to specific approach is employed, starting with the $p=9$, to obtain a final specification for equation 1 , eliminating non-significant lags at the $5 \%$ significance level. The software package RATS9.20 was used.

Regarding testing for significance, it should be noted that the t-test is symmetrical, but as variances from the Kalman Filter are positive or zero, the significance test must be modified to account for the non-negativity restriction. Gouriéroux et al. (1982) show that the null distribution of the parameters is a combination of $\chi^{2}$ - statistics with degrees of freedom depending on the number of zero-constraints simultaneously tested. For example, to test if one of the constrained parameters - and only that one - is zero, then the distribution of the test statistic - which is calculated as the square of the usual t-statistic - is $\frac{1}{2} x^{2}(0)+\frac{1}{2} x^{2}(1)$, where $x^{2}(0)$ is a truncated chisquared distribution with unit mass at the origin and $x^{2}(1)$ is a chi-squared statistic with one degree of freedom. Moreover, a $x^{2}(1)$ distribution is equivalent to the standard normal distribution or $\mathrm{z}$ distribution. Therefore, the z-score is used to test for significance of the parameters. The parameters are estimated in RATS9.20 by using the maximum likelihood method. More details can be found in the RATS 9.20 (2017) manual.

In this autoregressive model the full data-set of wine production is used: VVR (1937-2016) and DR (1933 to 2013).

The comparison of the models developed for each region were performed through Adjusted R-squared and AIC in this case, lower values of this criterion correspond to a better model fit.

\section{Second Step: Spectral analysis}

The focus of this paper is to analyze the spectral properties of WP. Like in Cunha and Richter (2014), the spectrum is calculated from equation 1. To do that, Fast Fourier Transform is used. As the regression coefficients vary over time so do the derived spectra. Technical details can be found in Cunha and Richter (2012).

\section{Third Step: Cross-Spectral Analysis}

As in the previous section, a state-space model for estimation is used. The difference is that the measurement equation contains an explanatory variable as well. Equation (3) below represents the 
measurement equation, and equation (4) represents the state equations. The estimation is again done using the Kalman filter as described above. Once the parameters are estimated in the time domain, they are transferred into the frequency domain. However, in this section the links between different wine production cycles are analysed using the coherence. The spectral coherence $\left(K_{X Y}^{2}\right)$ will always be in the interval $0 \leq K_{X Y}^{2} \leq 1$ like the $\mathrm{R}^{2}$ in the time domain. As the spectra are time varying so is the coherence.

In order to avoid multicollinearity, only the relationship between two variables $\left\{\mathrm{y}_{\mathrm{t}}\right\}$ and $\left\{\mathrm{x}_{\mathrm{t}}\right\}$ is estimated, where $\left\{\mathrm{y}_{\mathrm{t}}\right\}_{\text {is }}$ the WP growth rate and $\left\{\mathrm{x}_{\mathrm{t}}\right\}$ is the temperature variability for example:

$\mathrm{V}(\mathrm{L})_{\mathrm{t}} \mathrm{y}_{\mathrm{t}}=\mathrm{A}(\mathrm{L})_{\mathrm{t}} \mathrm{x}_{\mathrm{t}}+\mathrm{u}_{\mathrm{t}}, \mathrm{u}_{\mathrm{t}} \sim$ i.i.d. $\left(0, \sigma^{2}\right)$

where $\mathrm{A}(\mathrm{L})_{\mathrm{t}}$ and $\mathrm{V}(\mathrm{L})_{\mathrm{t}}$ are lag polynomials, and $\mathrm{L}$ is the lag operator such that $L z_{t}=z_{t-1}$. Notice that the lag structure, $\mathrm{A}(\mathrm{L})_{\mathrm{t}}$, is time-varying. It is assumed and tested whether the estimated coefficients follow a random walk such as:

$\mathrm{v}_{\mathrm{i}, \mathrm{t}}=\mathrm{v}_{\mathrm{i}, \mathrm{t}-1}+\varepsilon_{\mathrm{i}, \mathrm{t}}$, for $\mathrm{i}=1, \ldots, \mathrm{p}$ and $\varepsilon_{\mathrm{i}, \mathrm{t}} \sim\left(0, \sigma_{\varepsilon_{\mathrm{i}}}^{2}\right)$

$a_{i, t}=a_{i, t-1}+\eta_{i, t}$, for $i=0, \ldots, q$ and $\eta_{i, t} \sim\left(0, \sigma_{\eta_{i}}^{2}\right)$
The random walk property is tested using the LaMotte-McWorther test, and for structural breaks, the fluctuations test is employed (Ploberger et al., 1989).

Since there is no available data prior 1941 for the weather station of Braga, the model for VVR uses the period of WP and weather data available, which is the period from 1941-2016.

\section{RESULTS AND DISCUSSION}

In this section, it is firstly presented the time-varying spectra and then the coherences between ST, SW and WP.

\section{Single Spectra of the Douro and Vinhos Verdes wine production}

Figure 2 shows the time series of wine production in the DR (1933-2013) and VVR (1937-2016). The series are more likely to present different degrees of temporal stationarity or non-stationary behaviour. Also, for most of the sample this time series show a lot of variation, which we analyse using the timefrequency approach.

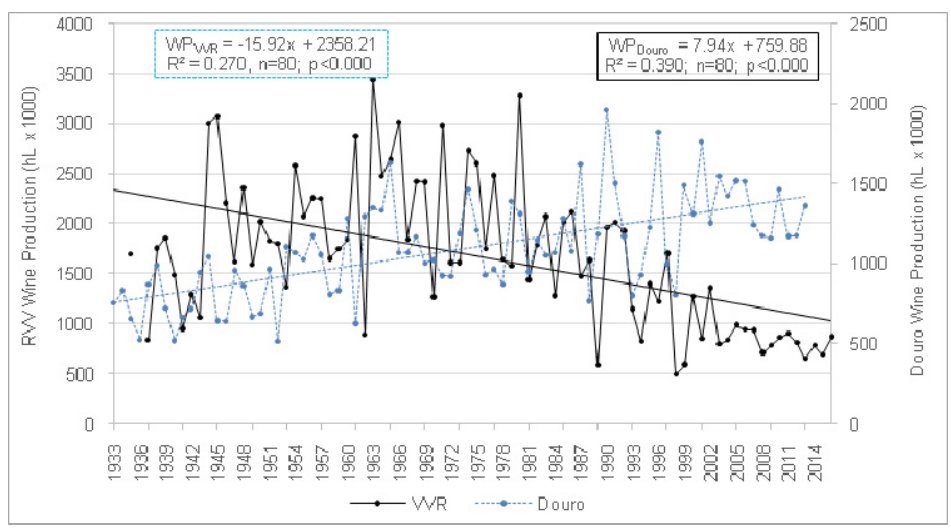

Figure 2. Time series and estimated linear trend of wine production for the period 1933 to 2013 in the Douro ( 80 observations) and the period 1937 to 2016 (79 observations) in Vinhos Verdes wine regions.

Séries temporais e tendência da produção de vinho no periodo 1933 a 2013 na região do Douro (81 observações) e no período 1937 a 2016 (80 observações) na região dos Vinhos Verdes.

There is an evident up-ward (DR) and down-ward (VVR) trend in wine production. The expected longterm trend in the times series of WP with more than
79 years is mainly a reflection of the changes in production area, vineyard practices and viticulture decisions such as changes in grape varieties. As the 
In both equations, only the $5^{\text {th }}$ lag is significant at the $5 \%$ significance level. However, in between the lag structure is different as the $4^{\text {th }}$ and $6^{\text {th }}$ lag is included but not the $1^{\text {st }}$. The developed time-varying autoregressive model explains $67 \%$ and $95 \%$ of the WP variability, respectively, in DR (Table I) and VVR (Table 2).

Table I

Results of the wine production (WP) autoregressive model, spring temperature (ST) and soil water in summer (SW) for the period 1933-2013 in Douro Region. Regression estimation made by the Kalman filter using 72 observations*

Resultados do modelo autoregressivo da produção de vinho (WP), temperatura média da primavera (ST) e água do solo no verão (SW) para o período de 1933-2013 na Região do Douro. Estimativa feita pelo filtro de Kalman usando 72 observações*

\begin{tabular}{|c|c|c|c|c|c|c|}
\hline \multicolumn{2}{|c|}{ Model summary and model adequacy } & \multicolumn{5}{|c|}{ Independent variables } \\
\hline Statistics & Value & Variable & Coeff & Std Error & T-Stat & Z_Sig \\
\hline \multicolumn{7}{|c|}{ Autoregressive model } \\
\hline & & Constant & 559.77 & 20.824 & 26.880 & 0.9999 \\
\hline R-Square & 0.670 & $\mathrm{WP}(-1)$ & -0.010 & 0.1356 & -0.076 & 0.5279 \\
\hline Radj-Square & 0.650 & WP(-2) & 0.019 & 0.119 & 0.157 & 0.5396 \\
\hline \multirow[t]{2}{*}{ AIC } & 539 & WP(-3) & 0.014 & 0.097 & 0.149 & 0.5557 \\
\hline & & WP(-5) & 0.456 & 0.043 & 10.457 & 0.9999 \\
\hline \multicolumn{7}{|c|}{ Spring Temperature (ST) } \\
\hline & & Constant & -237.34 & $1.46 \mathrm{E}^{-05}$ & $-1.60 \mathrm{E}^{+07}$ & 0.9999 \\
\hline R-Square & 0.674 & $\mathrm{WP}(-1)$ & -0.074 & 0.047 & -1.564 & 0.9406 \\
\hline Radj-Square & 0.654 & WP(-5) & 0.217 & 0.043 & 4.989 & 0.9999 \\
\hline \multirow[t]{3}{*}{$\mathrm{AIC}$} & 317 & ST & 104.36 & 3.14 & 33.19 & 0.9999 \\
\hline & & ST(-2) & -6.87 & 2.66 & -2.58 & 0.9951 \\
\hline & & ST $(-3)$ & -22.59 & 2.86 & -7.90 & 0.9999 \\
\hline \multicolumn{7}{|l|}{ Soil Water (SW) } \\
\hline & & Constant & 598.12 & 42.53 & 14.06 & 0.9999 \\
\hline R-Square & 0.844 & WP & 0.046 & 0.076 & 0.605 & 0.7257 \\
\hline Radj-Square & 0.832 & WP(-3) & 0.127 & 0.104 & 1.217 & 0.8869 \\
\hline \multirow[t]{4}{*}{ AIC } & 283 & WP(-5) & 0.332 & 0.106 & 3.14 & 0.9992 \\
\hline & & SW & -5.42 & 0.23 & -23.40 & 0.9999 \\
\hline & & SW(-2) & 2.04 & 0.15 & 13.36 & 0.9999 \\
\hline & & SW $(-3)$ & 2.76 & 0.20 & 13.74 & 0.9999 \\
\hline
\end{tabular}

The time-varying spectrum presented in Figure 3, which is based on the autoregressive model presented on Table I for DR, shows the dynamic characteristics of the WP. Over the entire frequency band, there are three distinctive peaks at frequencies $0.1,1.1$ and 2.5 .

The relationship between period $(\mathrm{P}$, years) and frequency $(\omega)$ is $\mathrm{P}=2 * \pi / \omega$. For example, a frequency of 0.1 basically represents the long run trend, which can be seen in the upper left hand corner of the Figure 3.

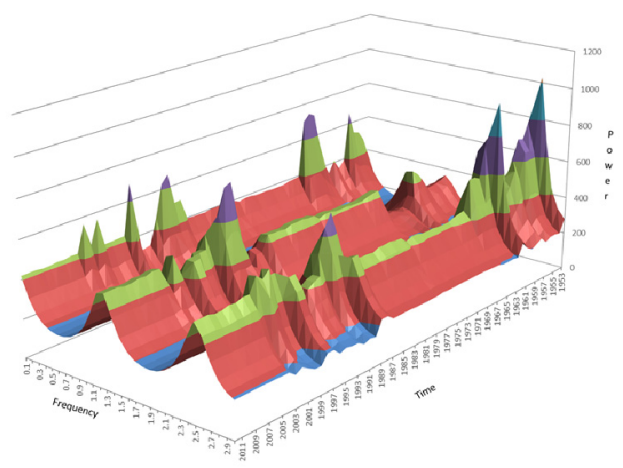

Figure 3. Time varying power spectrum of the wine production for the period 1933-2013 in Douro Region.

Variação temporal da potência da distribuição espectral da produção regional de vinho no período 1933 a 2013 na Região do Douro. 
Table II

Results of the wine production (WP) autoregressive model, mean spring temperature (ST) and soil water in summer (SW for the period 1937-2016 in Vinhos Verdes Region. Regression estimation made by the Kalman filter using 71 (autoregressive model) and 67 (climate models) observations*

Resultados do modelo autoregressivo da produção de vinho (WP), temperatura média da primavera (ST) e água do solo no verão (SW) para o periodo de 1937-2016 na região de Vinhos Verdes. Estimativa feita pelo filtro de Kalman usando 71 (modelo autoregressivo) e 67 (modelos climáticos) observações*

Model summary and model adequacy

\begin{tabular}{|c|c|c|c|c|c|c|}
\hline Statistics & Value & Variable & Coeff & Std Error & T-Stat & Z_Sig \\
\hline \multicolumn{7}{|c|}{ Autoregressive model } \\
\hline & & Constant & 523.9 & 1.85 & 282.81 & 0.9999 \\
\hline R-Square & 0.955 & $\mathrm{WP}(-2)$ & -0.028 & 0.151 & -0.184 & 0.7995 \\
\hline Radj-Square & 0.953 & WP(-3) & -0.116 & 0.195 & -0597 & 0.5199 \\
\hline \multirow[t]{3}{*}{$\mathrm{AIC}$} & 1119 & WP(-4) & -0.020 & 0.155 & -0.129 & 0.5478 \\
\hline & & WP(-5) & 0.450 & 0.206 & 2.186 & 0.9854 \\
\hline & & WP(-6) & -0.013 & 0.160 & -0.083 & 0.5319 \\
\hline \multicolumn{7}{|c|}{ Spring Temperature (ST) } \\
\hline & & Constant & 3492.48 & 115.30 & 30.291 & 0.9999 \\
\hline R-Square & 0.991 & WP(-1) & -0.611 & 0.066 & -9.138 & 0.9999 \\
\hline Radj-Square & 0.990 & $\mathrm{WP}(-2)$ & -0.126 & 0.075 & -1.669 & 0.9515 \\
\hline \multirow[t]{4}{*}{ AIC } & 2140 & WP(-3) & -0.227 & 0.228 & -0.998 & 0.8389 \\
\hline & & ST & 84.343 & 24.626 & 3.425 & 0.9997 \\
\hline & & $\mathrm{ST}(-2)$ & -151.18 & 31.60 & -4.784 & 0.9999 \\
\hline & & ST(-6) & -45.68 & 13.344 & -3.424 & 0.9997 \\
\hline \multicolumn{7}{|l|}{ Soil Water (SW) } \\
\hline & & Constant & 1725.76 & 38.011 & 45.402 & 0.9999 \\
\hline R-Square & 0.962 & $\mathrm{WP}(-2)$ & 0.068 & 0.121 & 0.556 & 0.7088 \\
\hline Radj-Square & 0.960 & $\mathrm{WP}(-3)$ & 0.293 & 0.059 & 1.979 & 0.9756 \\
\hline \multirow[t]{3}{*}{$\mathrm{AIC}$} & 686 & WP(-6) & -0.056 & 0.167 & -0.333 & 0.6255 \\
\hline & & SW & -1.944 & 0.170 & -11.413 & 0.9999 \\
\hline & & SW $(-5)$ & -0.244 & 1.179 & -0.207 & 0.5793 \\
\hline
\end{tabular}

作 observations refers at end of the sample. AIC - Akaike Information Criterion. The number after each dependent variable represents the lag to the actual season. For example WP(-3) and WP(-5): are, respectively, the $3^{\text {rd }}$ and the $5^{\text {th }}$ lag of WP. Units: WP $\left(\mathrm{hL} \times 10^{3}\right)$, $\mathrm{ST}\left({ }^{\circ} \mathrm{C}\right)$ and SW $(\mathrm{mm})$

Hence, currently WP is characterised by a long run trend (frequency 0.1) and two shorter cycles of 5.7 years (frequency 1.1) and 2.5 years (frequency 2.5). This means that the time span from one peak in WP to another is close to 6 and 2.5 years, respectively. As one can see, all three cycles are equally important, which is particularly relevant for the last five years of the sample. In between the cycles vary, for example during the 1990s. Previously, Cunha and Richter (2012) developed a time-varying parameter model for the DR vs WP based on the ST for the period 1966 to 2007. It is worth noting that although the regression results are very similar to those of Cunha and Richter (2012) for the DR' WP for the period 1966 to 2007, the availability of new data (1933 to 2013) meant that the second important cycle is now 5.7 years instead of 4.7 years. That is, the new data shifted the second cycle by one year approaching it to the 4.7-year cycle found in the VVR for the period (1937-2016).

Figure 4 shows the time-varying spectrum of the VVR WP, which is based on autoregressive model presented in Table II.

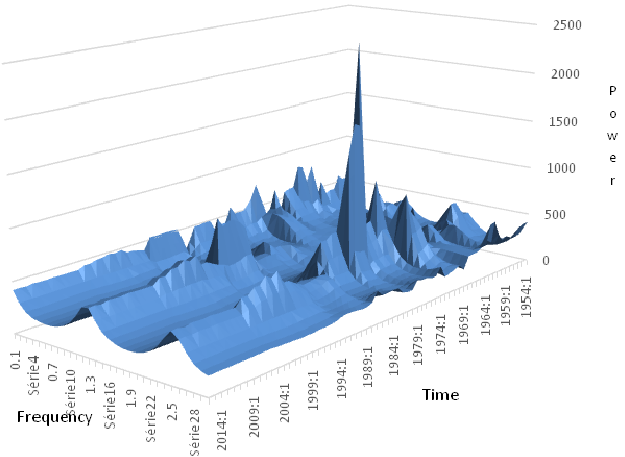

Figure 4. Time varying power spectrum for the wine production for the period 1937-2016 in Vinhos Verdes Region.

Variação temporal da potência da distribuição espectral da produção regional de vinho no período 1937 a 2016 na Região dos Vinhos Verdes. 
As can be seen from Figure 4 the VVR power spectrum is towards the end of the sample characterised by three dominant frequencies: the long run trend, the frequency of 1.3 and 2.6, which corresponds to the 4.8 and 2.4 year cycles, respectively. In this region, the WP cycles emerged at the beginning of the 1990s whilst for the DR the cycles were apparent throughout the sample. Therefore, it is fair to conclude that VVR production cycles converged towards the DR cycles and not the other way round. Before the 1990s, the VVR production cycles appear to be fairly unsettled with a spike in 1979 at a frequency of 2.1 (3 years). Up to the 1990s this frequency, together with the long-run trend, was the dominant one although its power was quite volatile until it disappeared (Figure 4). Notably, these two WP cycles around 5-6 years and 2.5 years detected in both regions are also consistent with other previous studies for VVR (Fraga et al., 2014) and Dão (Esteves and Orgaz, 2001) Portuguese wine regions.

In summary, the WP spectrum in both regions are characterised by a long run trend coupled with two shorter cycles. The great influence of the long run trend in DR and VVR confirms the results presented in Figure 2

In terms of shorter cycles, it is remarkable that both regions exhibit only two more dominant cycles. The medium cycle is one year apart from each other whilst the short-term cycle is close to one year apart from each other. Therefore, the spectra of both regions are relatively close to each other.

\section{Coherence of wine production in Douro and} Vinhos Verdes wine regions

In both regions, the dependence of the WP on the ST and SW, using a bi-variable approach in order to avoid potential multicollinearity, is estimated, that is, the two explanatory variables may be correlated with each other, making the model not estimable anymore.

\section{Effect of Spring temperature on wine production}

Figure 5 presents the cross spectrum for DR_WP and ST based on regression results presented in Table I.

In comparison to the autoregressive model (Table I), the regression with ST presents similar values for $\mathrm{R}_{\mathrm{adj}}$-square (0.65). However, this model with the $\mathrm{ST}$ is preferable to the autoregressive one for the lower AIC value (317 in comparison to 539), which of course does not mean that it is the "best" possible model, as the AIC does not reflects the absolute quality of a model. The WP in DR can be modelled using ST. At the end of the sample the current ST as well as the ST of previous two (ST2) and three years
(ST3) have significant impact on the WP. In opposition to the current ST, an increase in the previous STs has a negative impact on WP. Also, the first and the $5^{\text {th }}$ lag of WP are both significant at the $5 \%$ significance level.

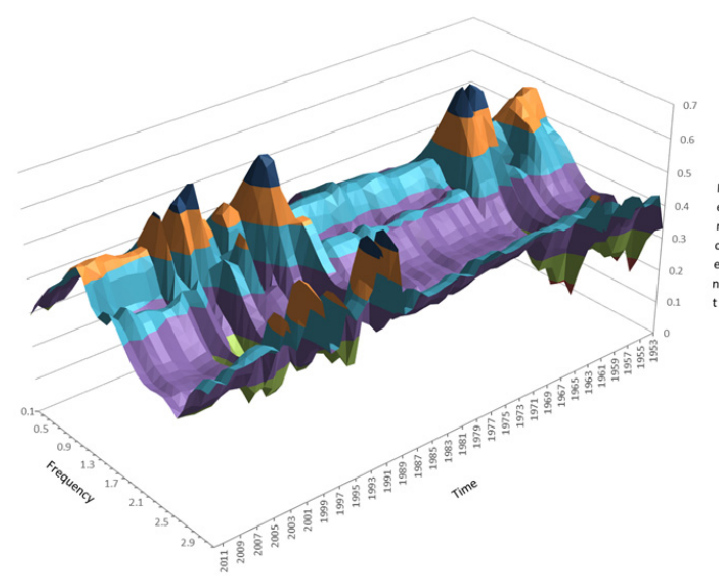

Figure 5. Coherence between wine production and spring temperature for the period 1933-2013 in Douro Region.

Coerência entre a produção de vinho e a temperatura média na primavera no período 1933-2013 na Região do Douro.

The regression of WP with ST for VVR presents high $\mathrm{R}_{\mathrm{adj}}$-square (0.99). However, in this model based on seven independent variables, the AIC value is higher than in the autoregressive one (five variables), despite the higher $R_{a d j}$-square. The AIC value is 2140 in comparison to 1119 (Table II). The relatively high $\mathrm{R}^{2}$ are not uncommon when working with the Kalman filter in general (e.g. Wells, 1996). In particular, one should note that the dynamic processes are fairly stable throughout the sample period as shown in the Figure 4, for example. Hence, there are no potential changes regarding the process to which the Kalman filter would have to adjust. Indeed, the estimated parameter values confirm that as they do not really change throughout the sample period.

As for the DR, the relationship between WP and ST in VVR is also time dynamic. At the end of the sample, WP depends on the first and second lag of WP but also on the ST in the current year as well as the ST of two (ST2) and six (ST6) previous years (all at 5\% significance level).

Based on these regressions (Table I and Table II) the coherence between WP and ST for DR (Figure 5) and VVR (Figure 6) regions is calculated.

It can see from Figure 5 that WP in DR is determined by ST through three main cycles. Although other cycles matter as well, the most important ones are assessed: the longer cycle at a frequency of 1.3 (5.8 
years), the medium term cycle at frequency 1.5 (4.2 years) and the short term cycle at frequency 2.9 (2.2 years), which has been happening since the 80 s. Since 2003, the link for the long run cycle has decreased from over $60 \%$ to just over $50 \%$. The medium cycle remained largely constant at $40 \%$, whilst the short term cycle decreased from $50 \%$ to $40 \%$ as well. This means that medium cycles have the same impact on WP than short term fluctuation. Taking into account the aforementioned aspects, the coherence is largely at a value where it was for a long time from the $1960 \mathrm{~s}$ to the 1990s. Therefore, relatively "low" values for the coherence can be considered as a return to previous values. The higher coherences were an exception than the rule. In difference to Cunha and Richter (2012) for the period 1966 to 2007 in DR, the higher number of observations of this model (1933 to 2013) led to two more variables to be significant: the first lag of WP and the second lag of ST. This implies that despite the lower number of observations, the initial regression was quite robust. In summary, in DR there is a stable but not constant link between the production and the ST. The temperature is still important for explaining about $60 \%$ the long term and short term behaviour of wine production, but its importance has decreased (Figure 5).

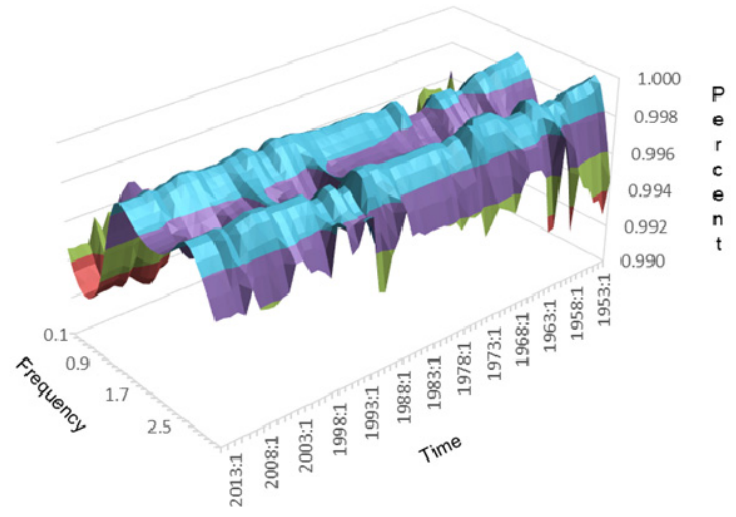

Figure 6. Coherence between wine production and spring temperature for the period 1941-2016 in the Vinhos Verdes Region.

Coerência entre a produção de vinho e a temperatura média na primavera no período 1941-2016 na Região dos Vinhos Verdes.

Figure 6 shows that the two pre-dominant cycles in VVR are at a frequency of 1.3 and 2.5, which correspond to 4.8 and 2.5 years cycles. The coherence of these two cycles is very stable throughout the sample. The longer cycle is just in between the 4.2 and 5.8 years cycles of the DR with the highest coherence. The shorter cycle is not far off the 2.2 years of the DR.
In both regions, the current-year impact of ST is positive, that is, an increase in current year ST will lead to a rise in WP of this year, while previous ST have a negative impact on WP. The biggest negative impact on WP has the ST of previous three years in DR and two years in VVR. The positive effect of current-year ST on WP is in line with the previous study for DR (Gouveia et al., 2011; Cunha and Richter, 2012; Santos et al., 2013; Cunha et al., 2016) and, VVR (Fraga et al., 2014), Spain (Lorenzo et al., 2013), Germany (Bock et al., 2013) and EUA (Lobell et al., 2007).

The positive impact of the ST on the WP could be related with more favourable conditions for physiological processes linked with grape yield that occur in Spring such as anthesis and fruit-set, which are favoured by warm and dry conditions (Cunha et al., 2003; May, 2004; Vasconcelos et al., 2009; Guilpart et al., 2014). Moreover, high spring temperature leads to anticipation of the phenological stages with great impact on avoiding soil water stress and, consequently on wine production (e.g. Reis et al., 2018). Therefore, this shortening of the vegetative cycle could results in less vegetative vigour and less accumulation of carbon in the plant's permanent structure (Mosedale et al., 2016). Thus, consecutive years of high ST may affect the production of the following years through the carryover effects of low carbon fixed and allocated to growth, as showed in the regressions developed for the DR (Table I) and VVR (Table II).

\section{Effect of soil water in summer on wine production}

In this section, the effects of SW on WP are investigated. As before, only the last regression's results for WP in DR and SW (Table I) are presented. This model is the basis for the coherence shown in Figure 7.

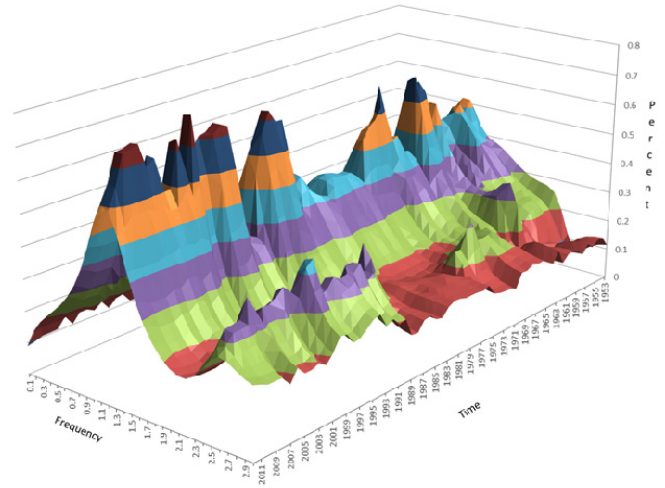

Figure 7. Coherence between wine production and soil water for the period 1933-2013 in Douro Region.

Coerência entre a produção de vinho e a água no solo no período 1933 a 2013 na Região do Douro. 
In comparison to the autoregressive and the ST model, the $R_{a d j}$-square is now higher $(0.83)$ for the DR. As this model has the lowest AIC value (283 in comparison to 317 for the ST model), this is the most preferred model of those presented for DR. Hence, SW is clearly more important to WP than ST when it comes to predicting WP in DR. However, ST is also important for WP as pointed out above.

The effects of SW in WP depend on the time (Table I). The immediate effect on current-year WP of an increase in SW is negative, whilst the SW that is in the ground, that is from the previous two and three years, have a positive effect on WP.

The regression between SW and WP for the VVR has

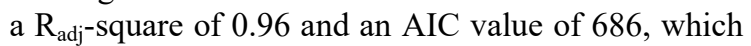
could be considered the most reliable model developed for the VVR (Table II).

As in the previous regression, WP is a dynamic process. It depends on the $3^{\text {rd }}$ lag of the WP and the same year SW. As shown above, the SW has a negative impact on the current year WP. In contrast to $\mathrm{DR}$, the impact of SW from the previous years does not have a significant effect on WP in the VVR.

Figure 7 shows that the coherence between WP and SW in DR is quite stable and centred around a frequency of 0.9 or 7 years as well as a short one cycle of 2.4 years which has been happening since the 1990s. However, it is evident that SW can explain 7 year cycles by $60 \%$ in recent years (since the late 1990 s). In previous years this link was in between $40 \%$ - $50 \%$. So, there is evidence that the impact of SW on WP increased over time. With regards to the 2.4 years cycle, this is even more evident: before the late $90 \mathrm{~s}$, SW could only explain an average $12 \%$ of the 2.4 year cycle. This has increased to $30 \%$. Remarkably, both changes took place in the same time period. Hence, from the late 90 s onwards, SW became particularly important for the long term WP and the shorter term WP. The fact that both events occurred at the same time (where both changes are statistically significant) indicates that this was not a random behaviour. The simple appearance of another cycle that has become important is an indicator in itself that available soil water has become more important for WP in DR.

Figure 8 shows the coherence between SW and WP for the VVR. For the entire sample there are three distinctive frequencies visible: the long-run trend, the frequency of 1.2 (or 5.2 years), and the frequency of 2.2 (or 1.5 years). Both, the long-run trend as well as the 5.2 years cycles have a coherence of around $80 \%$. The shorter cycle has a coherence of $86 \%$ at the end of the sample. Throughout the sample the coherence of these three cycles varies. The long run trend's coherence has been slowly reduced. The medium cycle was quite volatile over the sample and recently (over the last five years) its coherence became smaller than the short cycle. As in the case of DR, this short cycle has gained importance (but not by as much as in the DR). It should also be mentioned that the "gain" of the short cycle was really owed to a loss of the coherence of the other cycles. Whilst for the DR the 7 years cycle is most important, for the VVR it is the 1.5 years cycle. In both cases, the main cycles are very distinct in the sense they have been present from the beginning of the sample.

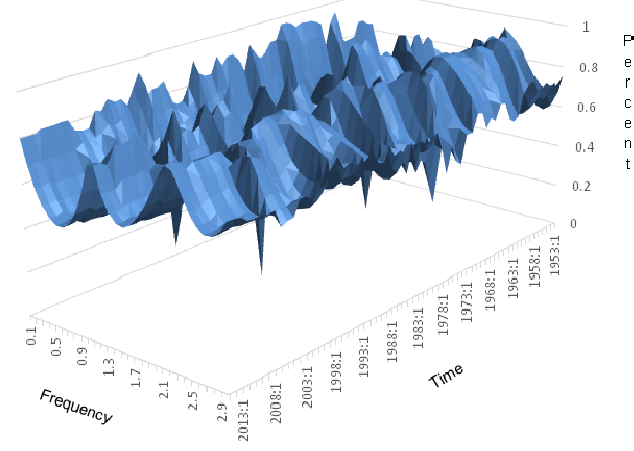

Figure 8. Coherence between soil water and wine production for the period 1941-2016 in the Vinhos Verdes Region.

Coerência entre a produção de vinho e a água no solo no período1941 a 2016 na Região dos Vinhos Verdes.

In both regions the $\mathrm{SW}$, compared with the autoregressive or ST model, yielded higher $R_{\text {adj- }}$ square $(>0.83)$ and lower AIC. Wine production depends more on SW than on ST. The SW has a negative impact on the WP of the current year in both regions, while the $\mathrm{SW}$ in the previous two or three years has a significant positive impact on WP in DR (Table I). The negative effect of SW on the WP of the current year is in line with the findings of other authors for different regions (Jones and Davis, 2000; Bock et al., 2013; Lorenzo et al., 2013; Fraga et al., 2014). In DR and VVR, as in many other hot and predominantly non-irrigated regions, a high level of $\mathrm{SW}$ is associated with a high vegetative vigour of the plants, conditions prone to increase the risk of infection and severity of fungal diseases (e.g. botrytis, downy mildew) and, consequently, potential harvest damages (Valdés-Gómez et al., 2011).

The other distinctive feature of the climate response in both regions is the carryover effects of summer hydric stress, and the consequent impact on the production in subsequent years. In DR, where it 
prevails non-irrigated vineyards, the SW of the previous two and three years have a positive effect on WP, suggesting that the precipitation during the rainy period (mainly autumn and winter) is not always enough to fill up the soil water reserve. Contrarily, in VVR the rain that occurs during the autumn and winter periods are generally enough to refill the SW, avoiding carryover effects of water deficits (SW5 not significant) that affects the WP in subsequent years as explained on the regression model (Table II).

\section{Cyclical properties of wine production in Douro and} Vinhos Verdes

The cyclical proprieties of wine production in DR and VVR are modelled using a time-frequency approach based on Kalm filter regressions for a long term period close to 80 years in both regions. The short time Fourier transform was used to decompose the link between WP and ST and SW. It is shown how many WP cycles in each region, and what cycle in particular, are explained by the ST and SW. This statistical approach have been successfully applied in a wide variety of disciplines, such as the analyses the impact of climate dynamics on wine yield (Cunha and Richter, 2012, 2016) and meadows growth (Cunha and Richter, 2014), as well as on economics applications (Hughes and Richter, 2003a, 2006). This work presents new insights on the robustness and transferability of the methodology developed in previous papers to test the impact of climate on cyclicality of the WP, by using a larger dataset for DR and a new dataset for another wine region (VVR) with strong technological change.

In summary, the ST and SW showed great capacity to explain the cyclicality of WP in the studied regions. The coherence between these two variables and the WP is temporarily much more stable in VVR than in the DR. This could be and indicator of lower impact of the foreseen climate scenarios in WP in the regions with a maritime climate, such as the VVR, when compared with hot and dry wine regions, which are in line with previous works (e.g. Ramakrishna et al., 2001). In DR, it can be recognised a shift of the relative importance away from ST to SW and, if in future temperature changes or more infrequent rainfalls as pointed by climatic scenarios, SW will be the limiting resource for WP in this region.

There is an evident increment on the WP' instability since the early 1990s in both regions. This volatility of WP could be related with climate change and/or technological changes throughout political decisions as a result of Portugal's integration on the European community (EC) that occurred in 1986. Subsequent to Portugal's entry into the EC, substantial changes occurred in the Portuguese wine regions, particularly in the restructuring/planting of new vineyards with a sharp reduction in the number of grape varieties in production (IVV, 2018). This lost on grape diversity will have led to a more vulnerable system even considering a plausible improvement of other cultural practices.

\section{CONCLUSIONS}

Wine production time-series in Douro and Vinhos Verde wine regions in the recent eighty years take the form of highly non-linear and non-stationary complex system, for which time-frequency is able to characterise the cyclical proprieties and the temporal variability of the relationship between climate and WP. This modelling approach can explain important proprieties inside the cycles of WP at different time scales and time frequencies. Despite the marked differences in the two studied regions on climate, soils, viticultural practices, as well as the period studied (DR: 1933-2013; VVR 1936-2016), and temporal trend of the production, the cyclicality proprieties of the WP in both regions is very similar and could be predicted by this modelling approach. It provides the cyclical proprieties of WP, the long-run cycles or technological trend using low frequencies and the short cycles based on high frequencies, as well as what cycles in particular are explained by ST and SW. Therefore, the authors believe this modelling approach are an encouraging first step to study other wine regions worldwide, towards developing more generalized models of WP cyclical proprieties.

Developed models for both regions suggest that stationary is a questionable assumption and this means that historical distributions of wine production are going to need dynamics updating. It should be considered when developing wine production models where climate plays an important direct or indirect role and climate variability is increasing as indicated by the recent IPCC reports. These wine production models are important for the investors, policy makers and all those whose business relies on wine supply chain, as well as for predicting the impact of climate variability on wine production cycles.

Improved analysis of the trend and cyclicality of wine production, what motivated them, their duration and periodicity and the model transferability among wine regions, is of paramount importance for the future wine industry policy, contributing for mitigation strategies facing an era of marked environmental and technological change in order to remain competitive in the market. 


\section{ACKNOWLEDGMENTS}

The authors would like to thank the Instituto dos Vinhos do Porto e Douro and Comissão de Viticultura da Região dos Vinhos Verdes for providing the wine production data.

\section{REFERENCES}

Allen R., 2015. Reference evapotranspiration calculator (Ref-ET). Available at: http://extension.uidaho.edu/kimberly/2013/04/ref-etreference-evapotranspiration-calculator/ (accessed on 2.06.2017).

Bindi M., Fibbi L., Gozzini B., Orlandini S., Miglietta F., 1996. Modelling the impact of future climate scenarios on yield and yield variability of grapevine. Clim. Res., 7, 213-224.

Bisson L.F., Waterhouse A.L., Ebeler S.E., Walker M.A., Lapsley J.T., 2002. The present and future of the international wine industry. Nature, 418, 696-669.

Bock A., Sparks T.H., Estrella N., Menzel A., 2013. Climateinduced changes in grapevine yield and must sugar content in Franconia (Germany) between 1805 and 2010. PloS one, 8, e69015

Bonnefoy C., Quenol H., Bonnardot V., Barbeau G., Madelin M., Planchon O., Neethling E., 2013. Temporal and spatial analyses of temperature in a French wine-producing area: the Loire Valley. Int. J. Climatol., 33, 1849-1862.

Cardell M.F., Amengual A., Romero R., 2019. Future effects of climate change on the suitability of wine grape production across Europe. Reg. Environ. Change, 19, 2299-2310.

Clingeleffer P., Dunn G., Krstic M., Martin S., 2001. Crop development, crop estimation and crop control to secure quality and production of major wine grape varieties: A national approach. Technical report, Australian Grape and Wine Authority. CSH 96/1, 136.

Cola G., Mariani L., Salinari F., Civardi S., Bernizzoni F., Gatti M., Poni S., 2014. Description and testing of a weather-based model for predicting phenology, canopy development and source-sink balance in Vitis vinifera L. cv. Barbera. Agric. For. Meteorol., 184, 117-136.

Cunha M., Abreu I., Pinto P., Castro R., 2003. Airborne pollen samples for early-season estimates of wine production in a Mediterranean climate of Northern Portugal. Am J. Enol. Vitic., 54, 189-194.

Cunha M., Marçal A.R.S., Silva L., 2010. Very early prediction of wine yield based on satellite data from vegetation. Int. J. Remote Sens., 31, 3125-3142.

Cunha M., Ribeiro H., Abreu I., 2016. Pollen-based predictive modelling of wine production: application to an arid region. Eur. $J$. Agron., 73, 42-54.

Cunha M., Richter C., 2012. Measuring the impact of temperature changes on the wine production in the Douro Region using the short time Fourier transform. Int. J. Biometeorol., 56, 357-370.

Cunha M., Richter C., 2014. A time-frequency analysis on the impact of climate variability on semi-natural mountain meadows. IEEE Trans. Geosci. Remote Sensing, 52, 6156-6164.

Cunha M., Richter C., 2016. The impact of climate change on the winegrape vineyards of the Portuguese Douro region. Clim. Change, 138, 239-251.
CVRVV, 2018. Dados estatísticos sobre a produção de vinho na Região dos Vinhos Verdes. Comissão de Viticultura da Região dos Vinhos Verdes. Available at: http://portal.vinhoverde.pt/pt/estatisticas (accessed on 9.12.2018).

Esteves M.A., Orgaz M.D.M., 2001. The influence of climatic variability on the quality of wine. Int. J. Biometeorol., 45, 13-21.

EU-CMO, 2019. Common market organisation (CMO), the wine market. Available at: https://ec.europa.eu/agriculture/wine_en (accessed on 17.05.2019).

Fraga H., Malheiro A.C., Moutinho-Pereira J., Santos J.A., 2014. Climate factors driving wine production in the Portuguese Minho region. Agric. For. Meteorol., 185, 26-36.

Fraga H., Santos J.A., 2017. Daily prediction of seasonal grapevine production in the Douro wine region based on favourable meteorological conditions. Aust. J. Grape Wine Res., 23, 296-304.

Fraga H., Santos J.A., Malheiro A.C., Oliveira A.A., MoutinhoPereira J., Jones G.V., 2016. Climatic suitability of Portuguese grapevine varieties and climate change adaptation. Int. J. Climatol., 36, $1-12$.

Giorgi F., Lionello P., 2008. Climate change projections for the Mediterranean region. Glob. Planet Change, 63, 90-104.

Gouriéroux C., Holly A., Monfort A., 1982. Likelihood ratio test, Wald Test, and Kuhn-Tucker test in linear models with inequality constraints on the regression parameters. Econometrica, 50, 63-80.

Gouveia C., Liberato M.L.R., Da Câmara C.C., Trigo R.M., Ramos M., 2011. Modelling past and future wine production in the Portuguese Douro Valley. Clim. Res., 48, 349-362.

Guilpart N., Metay A., Gary C., 2014. Grapevine bud fertility and number of berries per bunch are determined by water and nitrogen stress around flowering in the previous year. Eur. J. Agron., 54, 9-

Hannah L., Roehrdanz P.R., Ikegami M., Shepard A.V., Shaw M.R., Tabor G., Zhi L., Marquet P.A., Hijmans R.J., 2013. Climate change, wine, and conservation. PNAS, 110, 6907-6912.

Hargreaves G., Samani Z., 1985. Reference crop evapotranspiration from temperature. Appl. Eng. Agric., 1, 96-99.

Hughes A.H., Richter C., 2003a. Learning and monetary policy in a spectral analysis representation. computational intelligence in economics and finance. In: Computational Intelligence in Economics and Finance. 91-103. Wang P., Chen. S.-H. (eds.). Springer Verlag, Berlin.

Hughes A.H., Richter C., 2006. Measuring the degree of convergence among European business cycles. Comput. Econ., 27, 229-259.

IPCC, 2007. Climate change (2007). Fourth assessment report of the intergovernmental panel on climate change. 939 p. Cambridge University Press, New York.

IVDP, 2018. Dados estatísticos sobre a produção de vinho do Douro e Porto na Região Demarcada do Douro. Instituto dos Vinhos do Douro e Porto. Available at: http://www.ivdp.pt/statistics (accessed on 29.08.2018).

IVV, 2018. Dados estatísticos sobre a produção de vinho em Portugal. Instituto da Vinha e do Vinho. Available at: http://portal.vinhoverde.pt/pt/estatisticas (accessed on 9.12.2018).

Johnson L., Pierce L., Michaelis A., Scholasch T., Nemani, R., 2006. Remote sensing and water balance modeling in California drip-irrigated vineyards. In: ASCE World Environmental \& Water Resources. Omaha, Nebraska, United States. 
Jones G.V., 2007. Climate Changes and the global wine industry. In: 13th Australian wine industry technical Conference. Adelaide, Australia.

Jones G.V., 2012. A climate assessment for the Douro wine region: an examination of the past, present, and future climate conditions for wine production. Associação para o Desenvolvimento da Viticultura Duriense, $67 . \quad$ Available at: http://www.advid.pt/imagens/outros/1368437718350.pdf (accessed on 21.08.2017).

Jones G.V., Davis R.E., 2000. Climate influences on grapevine phenology, grape composition, and wine production and quality for Bordeaux, France. Am J. Enol.Vitic., 51, 249-261.

Lobell D., Cahill K., Field., 2007. Historical effects of temperature and precipitation on California crop yields. Clim. Change, 81, 187203.

Lorenzo M.N., Taboada J.J., Lorenzo J.F., Ramos A.M., 2013. Influence of climate on grape production and wine quality in the Rías Baixas, north-western Spain. Reg. Environ. Change, 13, 887896.

Martins A., Mestre S., Gonçalves E., 1998. Estabilidade do rendimento de clones de videira (in portuguese). In: $4^{\circ}$ Simpósio de Vitivinicultura do Alentejo, Évora, Portugal.

Maxwell J.T., Ficklin D.L., Harley G.L., Jones G.V., 2016. Projecting future winegrape yields using a combination of Vitis vinifera $\mathrm{L}$. growth rings and soil moisture simulations, Northern California, USA. Aust. J. Grape Wine Res., 22, 73-80.

May P., 2004. Flowering and fruitset in grapevines. Lythrum Press, Adelaide.

Maybeck P., 1979. Stochastic models, estimation, and control. Vol 1, 424 p. Academic Press, New York

Moriondo M., Jones G.V., Bois B., Dibari C., Ferrise R., Trombi G., Bindi M., 2013. Projected shifts of wine regions in response to climate change. Clim. Change, 119, 825-839.

Mosedale J.R., Abernethy K.E., Smart R.E., Wilson R.J., Maclean I.M.D., 2016. Climate change impacts and adaptive strategies: lessons from the grapevine. Globl Change Biol., 22, 3814-3828.

Peterson T.C., Easterling D.R., Karl T.R., Groisman P., Nicholls N., Plummer N., Torok S., Auer I., Boehm R., Gullett D., Vincent L., Heino R., Tuomenvirta H., Mestre O., Szentimrey T., Salinger J., Førland E.J., Hanssen-Bauer I., Alexandersson H., Jones P., Parker D., 1998. Homogeneity adjustments of in situ atmospheric climate data: a review. Int. J. Climatol., 18, 1493-1517.
Pierce L., Nemani R., Johnson L., 2015. VSIM - Vineyard Soil Irrigation Model - release 3/1/06 - User Guide. Available at: http://geo.arc.nasa.gov/sge/vintage/vsim_050103_guide.pdf (assessed on 29.01.2015).

Ploberger W., Krämer W., Kontrus K., 1989. A new test for structural stability in the linear regression model. J. Econom., 40 307-318.

Quiroga S., Iglesias A., 2009. A comparison of the climate risks of cereal, citrus, grapevine and olive production in Spain. Agric.Syst., 101, 91-100.

Ramakrishna R.N., Michael A.W., Daniel R.C., Gregory V.J., Steven W.R., Joseph C.C., David L.P., 2001. Asymmetric warming over coastal California and its impact on the premium wine industry. Clim. Res., 19, 25-34.

Reis M.P., Ribeiro H., Abreu I., Eiras-Dias J., Mota T., Cunha M., 2018. Predicting the flowering date of Portuguese grapevine varieties using temperature-based phenological models: a multi-site approach. J. Agric. Sci., 156, 865-876.

Santos J.A., Grätsch S.D., Karremann M.K., Jones G.V., Pinto J.G., 2013. Ensemble projections for wine production in the Douro Valley of Portugal. Clim. Change, 117, 211-225.

Santos J.A., Malheiro A.C., Karremann M.K., Pinto J.G., 2011 Statistical modelling of grapevine yield in the Port Wine region under present and future climate conditions. Int. J. Biometeorol., 55, 119-131

Teslić N., Vujadinović M., Ruml M., Ricci A., Vuković A. Parpinello G.P., Versari A., 2019. Future climatic suitability of the Emilia-Romagna (Italy) region for grape production. Reg. Environ. Change, 19, 599-614.

Valdés-Gómez H., Gary C., Cartolaro P., Lolas-Caneo M., Calonnec A., 2011. Powdery mildew development is positively influenced by grapevine vegetative growth induced by different soil management strategies. Crop Prot., 30, 1168-1177.

Vasconcelos M.C., Greven M., Winefield C.S., Trought M.C.T., Raw V., 2009. The Flowering process of Vitis vinifera: A review. Am J. Enol.Vitic., 60, 411-434.

Wells C., 1996. The Kalman Filter in Finance. 171 p. Kluwer Academic Publishers, Dordrecht.

Ye T., Nie J., Wang J., Shi P., Wang Z., 2015. Performance of detrending models of crop yield risk assessment: evaluation on real and hypothetical yield data. Stoch. Environ. Res. and Risk Assess., 29, 109-117. 